\title{
BEHAVIORAL FLEXIBILITY OF TEMPORAL SUBCASTES IN THE FIRE ANT, SOLENOPSIS INVICTA IN RESPONSE TO FOOD
}

\author{
By A. Ann Sorensen*, T. M. Busch, and S. B. Vinson \\ Department of Entomology, \\ Texas A \& M University, College Station, Texas 77843
}

\section{INTRODUCTION}

Most social insects are characterized by the presence of a caste system (Oster and Wilson 1978). Castes are functionally defined as any set of colony members, smaller than the society itself, that specialize on particular tasks for prolonged periods of time (Michener 1974; Oster and Wilson 1978). The performance of these tasks may be correlated with size (physical castes) or age (temporal castes) of the worker. As a rule, workers in physical castes cannot shift easily from one role to another. They tend to specialize in certain tasks predetermined by their brain structure, sensory physiology, and innate behavior patterns (Oster and Wilson 1978). In contrast, workers in temporal castes usually follow an age-related progression from nurse duties to nest duties to foraging. Studies on temporal castes in honeybees (Nolan 1924; Rösch 1930) and ants (Ehrhardt 1931; Dobrzańska 1959; Chavin 1969; Lenoir 1979) showed that this progression is not necessarily rigid. Workers can respond to colony needs by altering either the rate or the direction of a typical behavioral sequence. In the present study, we examined the behavioral flexibility of the temporal caste system of the fire ant, Solenopsis invicta Buren.

Fire ant workers are weakly polymorphic and show slight allometry with continuous size variation and three arbitrarily demarcated size categories of workers in mature colonies (Wilson 1953; 1978). Superimposed on these morphological castes is a temporal division of labor which largely determines which tasks will be performed

\footnotetext{
*Present address and correspondence: A.A. Sorensen, Department of Agriculture, Agricultural and Environmental Science Program, P.O. Box 12847, Austin, Texas 78711

Manuscript received by the editor Ma!' 10, 1984.
} 
(Mirenda and Vinson 1981). There are two behaviorally discrete subcastes, nurses and foragers, and a third intermediate subcaste, reserves, that are transitional in behavior. Workers typically progress from nursing to nest maintenance to foraging. However, they progress at different rates depending on size which, in turn, is correlated with longevity.

To access the flexibility of the temporal caste system, we focused on tasks that were critical to the survival of the colony: the maintenance of an adequate food supply to the queen and brood. The use of radioiodinated protein and differentially marked subcastes enabled us to trace resource flow through the colony. Normally, foragers exclusively forage, nurses exclusively tend brood, and reserves mainly relay food from foragers to nurses (Mirenda and Vinson 1981; Sorensen et al. 1981). By selectively eliminating temporal subcastes we were able to assess the ability of the remaining subcastes or subcaste to alter their current response behavior to food and replace the missing workers.

\section{Materials AND Methods}

Ants used in these experiments were from polygynous colonies collected in College Station, Texas. Laboratory maintenance procedures were as described previously (Sorensen and Vinson, 1981). To separate temporal subcastes, colonies were transferred to behavioral distribution nests (Sorensen et al. 1981) and separated by their location inside and outside the nest during food presentation. Subcaste members were then chosen at random and marked with fine colored wires (Mirenda and Vinson 1979). They were placed in two stacked clear plastic cylinders $(7 \mathrm{~cm}$ high, $10 \mathrm{~cm}$ diam., Sorensen and Vinson 1981) with the upper chamber as a foraging area and the lower chamber containing a small shell vial to serve as a brood chamber. Brood and queens from the mother colony were added and held with the workers for $24 \mathrm{~h}$. Radioiodinated albumin mixed with egg yolk powder (Sorensen and Vinson 1981) was then placed in the upper foraging chamber and replenished as needed over 7 days. Radioactivity was measured with a Searle 1195 gamma radiation counter. Workers were measured daily in gelatin capsules and returned to their respective containers (Sorensen et al. 1980). Larvae were measured together in one capsule to minimize handling. 
Members of the three temporal subcastes were tested by themselves (i.e., two subcastes excluded) and in paired combinations to determine if adequate food flow could be maintained. Three replications. of the following groups were tested using a different colony ( $\mathrm{A}, \mathrm{B}$, and $\mathrm{C}$ ) each time. With two of the three subcastes excluded, we tested 50 foragers (F), 50 larvae (L), and 1 queen $(\mathrm{Q})$; 50 reserves $(\mathrm{R}), 50 \mathrm{~L}$, and $1 \mathrm{Q}$; and 50 nurses $(\mathrm{N}), 50 \mathrm{~L}$, and $1 \mathrm{Q}$. With one subcaste excluded we tested combinations of $25 \mathrm{~F} / 25 \mathrm{~N}$, $50 \mathrm{~L}, 1 \mathrm{Q} ; 25 \mathrm{~F} / 25 \mathrm{R}, 50 \mathrm{~L}, 1 \mathrm{Q}$; and $25 \mathrm{R} / 25 \mathrm{~N}, 50 \mathrm{~L}, 1 \mathrm{Q}$. Five replications using workers from all three subcastes were tested as a control using $18 \mathrm{~F} / 18 \mathrm{R} / 18 \mathrm{~N}, 50 \mathrm{~L}$, and $1 \mathrm{Q}$. Different colonies from those previously tested were used.

To determine the biological half-life of the radiolabelled protein in the different groups tested (Sorensen et al. 1980) control colonies were set up as described previously, allowed to feed for $1 \mathrm{~h}$, and held for 7 days without food. All of the ants were measured daily for radioactivity as described previously.

Statistical analyses were done using the Statistical Analysis System (SAS) for computer data analysis. We used a SAS REG procedure for full rank linear model analysis, regressing the amount of food in each ant against the total amount of food in the colony. Multiple comparisons among slopes were made using the NewmanKeul Multiple Range Test (Zar 1974). Duncan's Multiple Range Test for means (SAS GLM procedure) was used to compare the mean amount of food collected by test colonies over time.

Behavioral observations were made on marked foragers and nurses to determine how flexible these subcastes were with regards to foraging and brood tending behavior. We isolated 100 nurses with larvae, marked them with wires, placed them in stacked cylinder nests as previously described, and presented them with food twice daily. Nurses that entered the foraging chamber were marked with a second wire loop. We then added 100 marked foragers and 100 reserves and observed them during feeding to see if the doubly marked N/F continued to forage or returned to brood tending. Three different colonies were tested. Foragers were tested in a similar manner except that foragers that stayed in the brood chamber were differentially marked and then later observed in the reconstituted colonies to see if they remained with the brood or returned to the nest periphery or foraging chamber. 


\section{RESULTS}

The biological half life of ${ }^{125} \mathrm{I}$-albumin in workers, queens, and larvae is shown in Fig. 1. Without any additional labeled food entering the colony, the level of radioactivity in queens and larvae dropped below $50 \%$ by the third day and remained at $40 \%$ and $11 \%$, respectively. The level of radioactivity in the workers stabilized at $65-70 \%$ after four days. This pattern was seen in all of the treatments, regardless of which subcastes were present. By superimposing this background pattern on those obtained when labeled food was allowed to enter the colony freely, we were able to estimate the amount of additional food distributed.

The relationship between total amount of food collected per colony and the partitioning of that food among subcaste members is illustrated in Figure 2. The daily amount of food collected per ant was regressed against the daily total of food collected by the colony. As the quantity of proteinaceous food in the colony increased, the rate at which the queen accumulated food was significantly higher than that of the larvae, reserves, nurses, and foragers. The rates at which larvae and reserves received food were significantly higher than that of the nurses and foragers.

A summary of the mean amount of food brought in by each colony over a one week period is shown in Figure 3. Three different colonies (A, B, and C) were used in the treatment groups and five other colonies used in the control groups. There were significant differences in the quantity of food collected by foragers, nurses, or reserves held by themselves. With nurses, a time delay of 3 days occurred before foraging was initiated. Paired worker subcastes also showed some variability in foraging activity. Overall, groups of foragers alone collected significantly more food than groups without foragers present with the exception of one $R / N$ trial. The food collected by a mixture of all 3 subcastes was similar to that collected by $\mathrm{R} / \mathrm{N}$ combinations or groups of nurses or reserves by themselves. There was, however, considerable variation in mean protein collected. Ants from colony $\mathrm{C}$ collected more food than ants from either colony A or B in most cases and ants from colony B collected less food in most cases.

Table 1 presents a summary of least square means (ug protein/ ant) using the total food per colony as a covariate. This minimizes the effect that quantity of food in the colony has on the food 


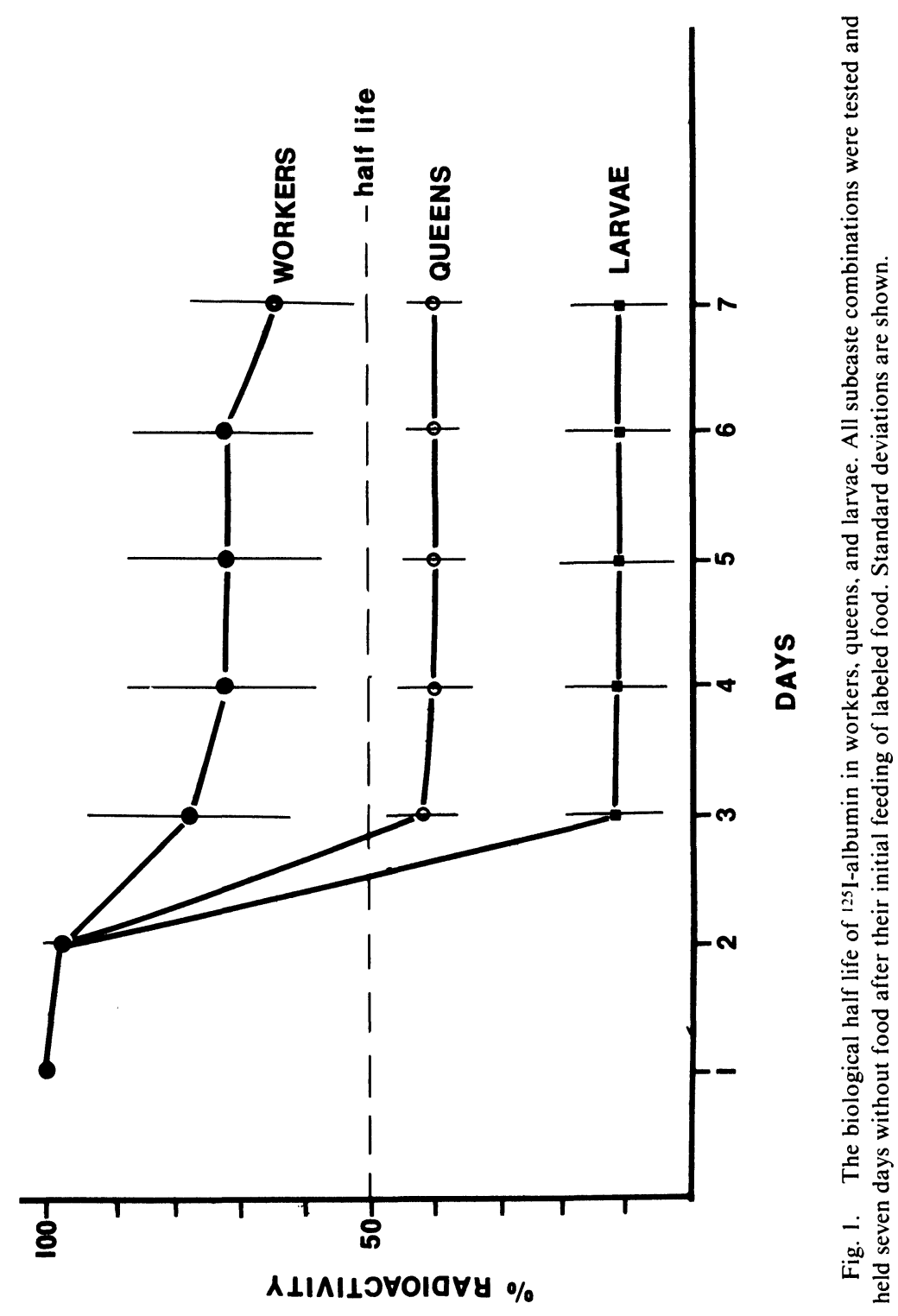




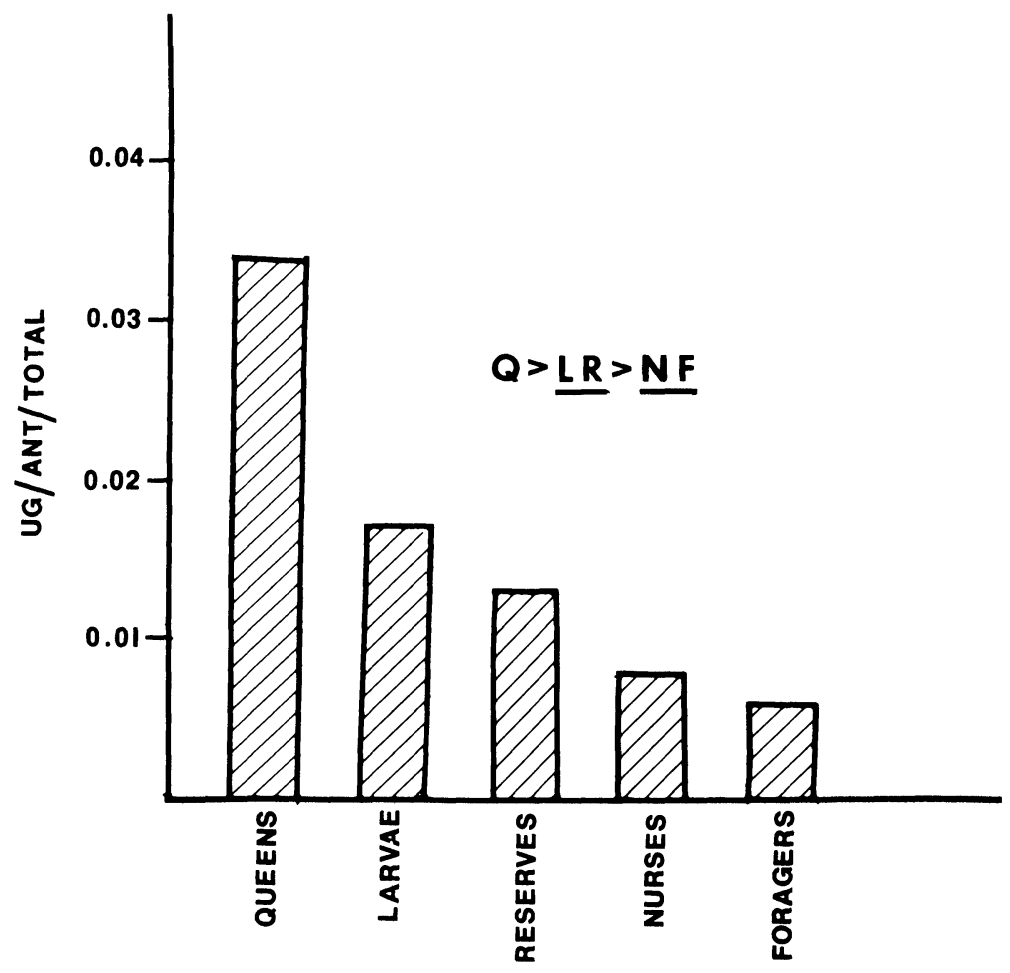

Fig. 2. The quantity of egg yolk per subcaste member is shown as a function of the amount of egg yolk in the colony. Underlined groups do not differ significantly at the $p=0.05$ level using the Newman-Keul Multiple Range Test.

collected per subcaste and enables us to compare feeding efficiency as if all of the colonies had collected the same amount of food. Larvae held with nurses or reserves received significantly more food than larvae tended by foragers alone. Larvae held with nurses and either reserves or foragers received significantly more food than larvae tended by foragers and reserves. Larvae in $F / N / R$ combinations received as much or more food than larvae tended by other subcaste combinations. Queens received significantly more food when tended by foragers alone than by either reserves or nurses. $\mathrm{F} / \mathrm{N}$ groups fed their queens significantly more food than either the $R / N$ or $F / R$ worker combinations. Overall, queens tended by foragers or foragers and nurses received significantly more food 


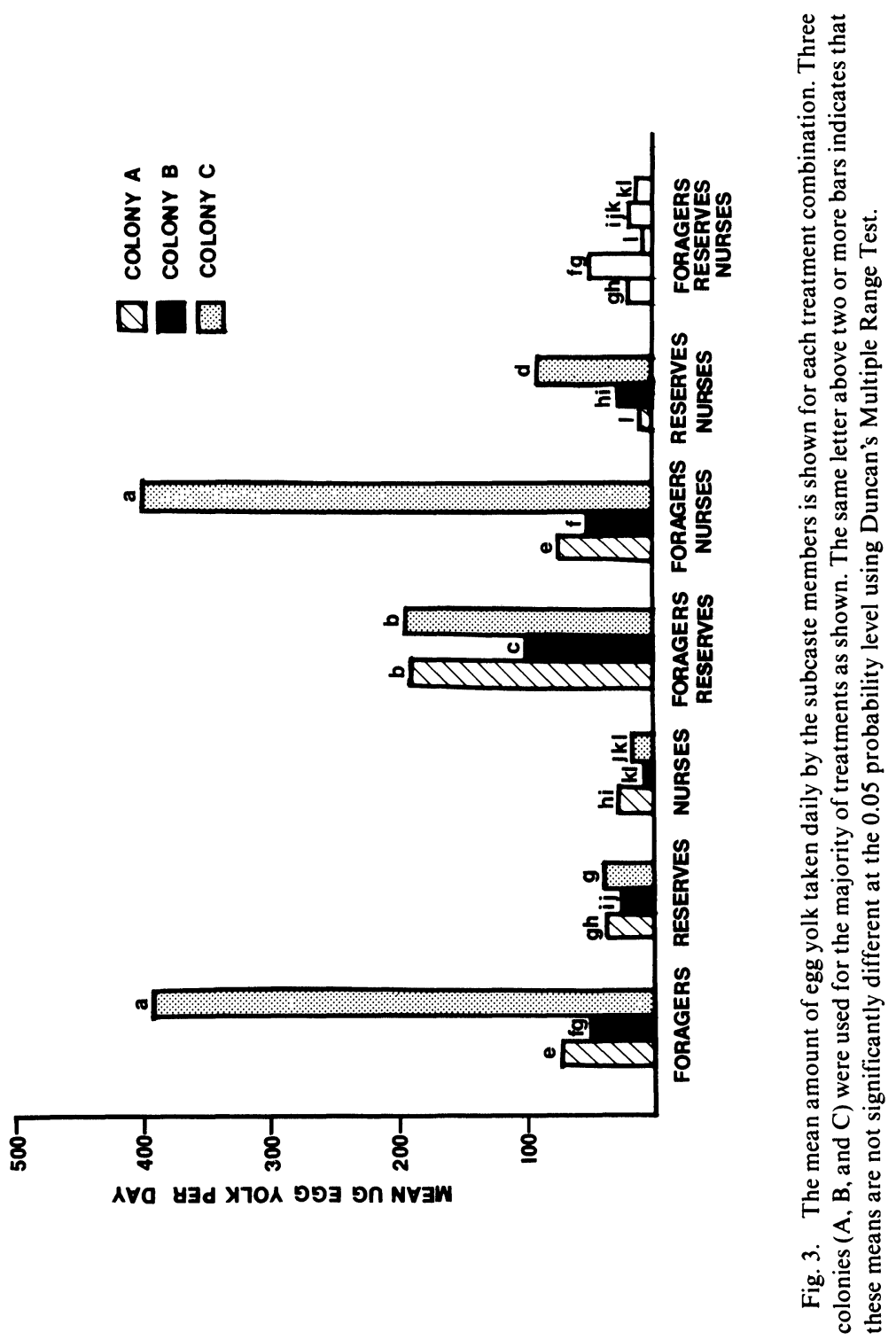


Table 1. Mean amount of food (ug) contained by foragers (F), reserves ( $R)$, nurses $(\mathrm{N})$, queens, and larvae in various tretment combinations. Least square means and standard error in parentheses are given using the amount of food per colony as a covariate.

\begin{tabular}{lccccccc}
\hline Subcaste & $\mathrm{F} / \mathrm{R}^{\prime}$ & $\mathrm{F} / \mathrm{N}$ & $\mathrm{R} / \mathrm{N}$ & $\mathrm{F}$ & $\mathrm{N}$ & $\mathrm{R}$ & $\mathrm{F} / \mathrm{N} / \mathrm{R}$ \\
\hline Foragers & $2.8 \mathrm{a}$ & $2.0 \mathrm{~b}$ & --- & $2.5 \mathrm{a}$ & -- & -- & $1.5 \mathrm{~b}$ \\
& $(0.8)$ & $(0.3)$ & & $(0.3)$ & & & $(0.3)$ \\
Reserves & $2.3 \mathrm{a}$ & --- & $0.9 \mathrm{~b}$ & --- & -- & $1.1 \mathrm{~b}$ & $0.8 \mathrm{~b}$ \\
& $(0.2)$ & & $(0.2)$ & & & $(0.2)$ & $(0.1)$ \\
Nurses & -- & $0.9 \mathrm{a}$ & $0.9 \mathrm{a}$ & -- & $0.6 \mathrm{~b}$ & -- & $0.7 \mathrm{~b}$ \\
& & $(0.1)$ & $(0.1)$ & & $(0.1)$ & & $(0.1)$ \\
Queens & $2.0 \mathrm{~b}$ & $5.3 \mathrm{a}$ & $0.8 \mathrm{~b}$ & $6.1 \mathrm{a}$ & $0.8 \mathrm{~b}$ & $1.5 \mathrm{~b}$ & $4.4 \mathrm{~b}$ \\
& $(1.2)$ & $(1.2)$ & $(1.2)$ & $(1.2)$ & $(1.6)$ & $(1.2)$ & $(0.8)$ \\
Larvae & $17.9 \mathrm{c}$ & $39.9 \mathrm{ab}$ & $42.3 \mathrm{ab}$ & $32.1 \mathrm{~b}$ & $42.1 \mathrm{ab}$ & $35.6 \mathrm{ab}$ & $43.8 \mathrm{a}$ \\
& $(4.3)$ & $(4.4)$ & $(4.2)$ & $(4.3)$ & $(5.2)$ & $(4.3)$ & $(2.9)$ \\
\hline
\end{tabular}

a. Least square means followed by different letters are significantly different at $p<$ 0.05 for each subcaste group. Larvae were measured together, 50 larvae per measurement.

than queens tended by other worker groups. Foragers paired with reserves or by themselves accumulated significantly more food than foragers paired with nurses or with nurses and reserves. Nurses received significantly more food when paired with either foragers or reserves than when paired with both foragers and reserves or left alone as a group. Reserves accumulated significantly more food when paired with foragers than when by themselves, paired with nurses, or held with both nurses and foragers.

When we observed marked nurses, we again saw a 3 day delay before any nurses entered the foraging chamber and only $10 \%$ of the nurses were foraging after one week (data not shown). When reserves and foragers were added, none of the marked nurse/ foragers returned to the brood chamber but remained on the nest periphery and at least $50 \%$ of them actively foraged for food. When isolated with brood, $50-60 \%$ of the foragers remained with the larvae and did not forage (data not shown). When nurses and reserves were added, only 5-10\% of these marked forager/nurses remained with the brood, $70 \%$ returned to the nest periphery, and $20 \%$ actively foraged for food. 


\section{Discussion}

Colony fitness in $S$. invicta is maintained by an efficient system of resource provisioning which is responsive both to the nutritional requirements and degree of hunger of its members and to how much food is available (Howard and Tschinkel 1981; Sorensen and Vinson 1981; Sorensen et al. 1983). In the present study, we utilized this system of resource provisioning to examine whether or not temporal subcaste members could change their roles of either feeding larvae (nurses), relaying food (reserves), or foraging (foragers) when other subcastes were removed.

We found that queens were fed protein preferentially regardless of amount available, presumably assuring their current and future reproductive output. Larvae were also fed protein preferentially as it entered the colony. The same partitioning of protein in response to supply was seen even after the experimental elimination of two of the three worker subcastes. This indicated that the behavior of workers was flexible enough to allow the colony to maintain priorities of resource provisioning even during severe disruption.

Foraging activity was greater in groups of foragers than in reserves or nurses and when they were present, significantly more food entered the colony than when they were absent. Similarly, nurses were slightly more active than reserves at feeding larvae and significantly more active than foragers. Reserves were intermediate between foragers and nurses in their ability to forage and feed larvae, performing the latter task more actively. Differences among colonies in feeding activity on egg yolk were reflected in similar differences among the subcastes isolated from those colonies. Differences in feeding preferences of fire ant colonies have been documented by Glunn et al. (1981) for both laboratory and field colonies.

Assessing the degree to which workers could switch to a different behavior, we found that reserves and nurses were considerably less active than foragers at food gathering. When nurses were grouped by themselves, they did not leave the brood chamber for 3 days and then only a few nurses ventured into the foraging chamber. The few foraging workers which appeared were probably mature nurses making the transition to reserve since marked nurse-foragers did not return to brood tending once colonies were reconstituted. However, 
this temporal behavior sequence may have been slightly accelerated by the absence of food as seen in Bombus sylvarum and other Bombus species (Free 1955). Acceleration of the development of behavior of younger workers in the absence of older workers has also been reported for the ant species Manica rubida (Ehrhardt 1931), Formica sanguinea (Dobrzanska 1959), Formica polyctena (Chauvin 1969), and Tapinoma erraticum (Lenoir 1977). These researchers found that groups of young workers of the same age quickly organize themselves into nurses and foragers. Lenoir (1979) found that this behavior was sometimes reversible and after a few days, young workers ceased foraging and became nurses again. In fire ants, however, nurses did not appear to be as flexible and did not resume active brood tending after foraging.

Reserves continued to tend brood when isolated as a group but also showed a limited tendency to forage. No delay in switching to foraging was evident. While reserves can be recruited by foragers for food collection (Sorensen et al. 1981), they normally do not leave the nest to forage on their own initiative (Mirenda and Vinson 1981). Similar differeneces in the capabilities of young and middleaged workers to shift to the roles of the oldest workers are seen in Pheidole dentata (Oster and Wilson 1978).

Isolated groups of foragers did feed and tend larvae in addition to foraging but remained primarily on the nest periphery when inactive rather than in the brood chamber where nurses or reserves were commonly found. Role flexibility in foragers with respect to brood tending has been seen in both Myrmica rubra (Ehrhardt 1931) and $M$. ruginodis (Weir 1958a, b). The immediate switch that we saw for both foragers and reserves to tending larvae when isolated with them argues against exocrine gland control of behavior as seen in M. rubra (Cammaerts-Tricot 1974) or B. hyphorum and B. terrestris (Röseler 1967).A delay in response would be expected if dormant exocrine glands had to be reactivated (Oster and Wilson 1978). Location in the nest may have been more important in determining probability of worker response. Seeley (1982) found that tasks performed by honeybees are strongly influenced by nest architecture. In the present study, proximity to larvae alone appeared to induce brood tending behavior by workers. The majority of foragers returned to foraging when nurses and reserves were added to their colonies. 
The queen continued to receive food regardless of which subcaste members were present, indicating that all workers were responsive to her needs. However, queens received more food from foragers than from nurses or reserves. This may have been related to the tendency of older ants to regurgitate food more readily than younger ants (Mirenda and Vinson 1981). It may also have been due to the presence of more food, increasing the probability that the queen would be fed (Howard and Tschinkel 1981). We do not know which subcaste members feed the queen in field colonies. Access to the queen, normally sequestered near the brood, may be limited to nurses and reserves. However, Brian and Jones (1980), in their studies with $M$. rubra, found that foragers associate with and pass food directly to the queen. They also cite similar findings for Oecophylla longinoda and Lasius niger. They feel that it may be a general phenomenon in all ants that foragers are more queen oriented and thus more susceptible to her influence over behavior than nurses.

In summary, these experiments indicated that the normal sequence of response behavior to food in fire ant workers could be altered. This ability of workers to switch to a new behavioral role in response to colony needs insures a steady flow of food to the queens and larvae. For fire ants, behavioral flexibility of workers greatly increases the chances of colony survival.

\section{ACKNOWLEDGMENTS}

The authors would like to thank Drs. Les Greenberg, Gale Smith, and David J. C. Fletcher and two anonymous reviewers for their helpful suggestions on early versions of this manuscript. The gamma radiation counter was kindly provided by Dr. Max D. Summers. This manuscript was approved as TA-19659 by the director of the Texas Agricultural Experiment Station. This research was supported in part by the Texas Department of Agriculture Agreement IAC(82-83)0982.

\section{REFERENCES}

Brian, M. V. AND R. M. Jones. 1980. Worker population structure and gyne production in the ant Myrmica. Behav. Ecol. \& Sociobiol. 7: 281-286.

Cammaerts-Tricot, M. C. 1974. Production and perception of attractive pheromones by differently aged workers of Myrmica rubra (Hymenoptera:Formicidae). Insectes Soc. 21: 235-247. 
Chauvin, R. 1969. Le monde des fourmis. Plon, edit, Paris, 287 pp.

DobrzańsKa, J. 1959. Studies on the division of labour in ants, genus Formica. Acta Biol. Exper. 19: 57-81.

Ehrhard, S. 1931. Uber Arbeitsteilung bei Myrmica und Messor-ARten. Z. Morph. Okol. Tiere 20: 755-812.

Free, J. B. 1955. The division of labor within bumblebee colonies. Insectes Soc. 2: $195-212$.

Glunn, F. J., D. F. Howard, and W. R. Tschinkel. 1981. Food preference in colonies of the fire ant, Solenopsis invicta. Insects Soc. 28: 217-222.

Howard, D. F. AND W. R. Tschinkel. 1981. The flow of food in colonies of the fire ant Solenopsis invicta: a multifactorial study. Physiol. Entomol. 6: 297-306.

LeNOIR, A. 1979. Feeding behaviour in young societies of the ant Tapinoma erraticum L.: trophallaxis and polyethism. Insectes Soc. 26: 19-37.

Michener, C. D. 1974. The Social Behavior of the Bees. A Comparative Study. The Belknap Press of Harvard University Press, Cambridge, Mass. $404 \mathrm{pp}$.

Mirenda, J. T. ANd S. B. Vinson. 1979. A marking technique for adults of the red imported fire ant. Fl. Entomol. 62: 279-280.

Mirenda, J. T. AND S. B. Vinson. 1981. Division of labour and specification of castes in the red imported fire ant Solenopsis invicta Buren. Anim. Behav. 29: 410-420.

Nolan, W. J. 1924. The division of labor in the honeybee. N. C. Beekeeper: $10-15$.

Oster, G. F. ANd E. O. Wilson. 1978. Caste and Ecology' in the Social Insects. Princeton University Press, Princeton, N. J. 352 pp.

Rosch, G. A. 1930. Untersuchungen über die Arbeitsteilung im Bienenstaat. 2. Teil. Die Tätigkeiten der Arbeitsbeinen unter esperimentell veränderten Bedingungen. Z. Vergl. Physiol. 12: 1-71.

Röseler, P. F. 1967. Arbeitsteilung und Drusenzustände in Hummelvölkern. Natur. 54: 146-147.

SeELEY, T. D. 1982. Adaptive significance of the age polyethism schedule in honeybee colonies. Behav. Ecol. Sociobiol. 11: 287-293.

Sorensen, A. A., T. M. Busch, AND S. B. Vinson. 1983. Behaviour of worker subcastes in the fire ant, Solenopsis invicta in response to proteinaceous food. Physiol. Entomol. 8:

Sorensen, A. A., R. Kamas, and S. B. Vinson. 1980. The biological half life and distribution of ${ }^{125}$ Iodide and radioiodinated protein in the imported fire ant, Solenopsis invicta Buren. Entomol. Exp. and Appl.28: 247-258.

Sorensen, A. A., J. T. Mirenda, And S. B. Vinson. 1981. Food exchange and distribution by three functional worker groups of the imported fire ant Solenopsis invicta Buren. Insectes Soc. 28: 383-394.

Sorensen, A. A., AND S. B. Vinson. 1981. Quantitative food distribution studies within laboratory colonies of the imported fire ant Solenopsis invicta Buren. Insectes Soc. 28: 129-160.

WeIR, J. S. 1958a. Polyethism in workers of the ant Myrmica. Insectes Soc. 5: 97-128.

WeIR, J. S. 1958b. Polyethism in workers of the ant Myrmica, II. Insectes Soc. 5: 315-339. 
WILSON, E. O. 1953. The origin and evolution of polymorphism in ants. Q. Rev. Biol. 28: 136-156.

WILSON, E. O. 1978. Division of labor in fire ants based on physical castes. J. Kans. Entomol. Soc. 51: 615-636.

Zar, J. H. Biostatistical Anal!sis. Prentice-Hall, Inc., Englewood Cliff, N. J. 620 $\mathrm{pp}$. 

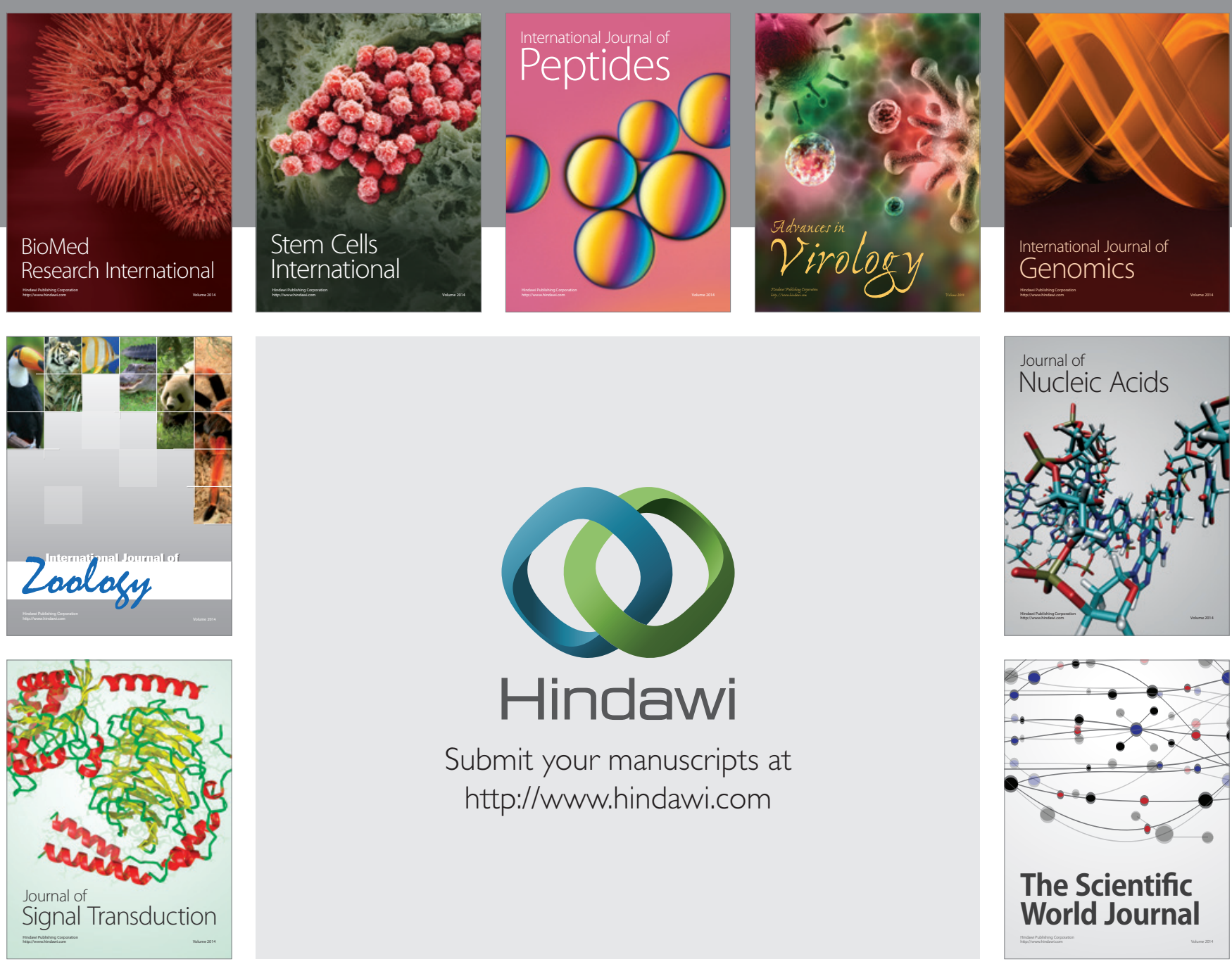

Submit your manuscripts at

http://www.hindawi.com
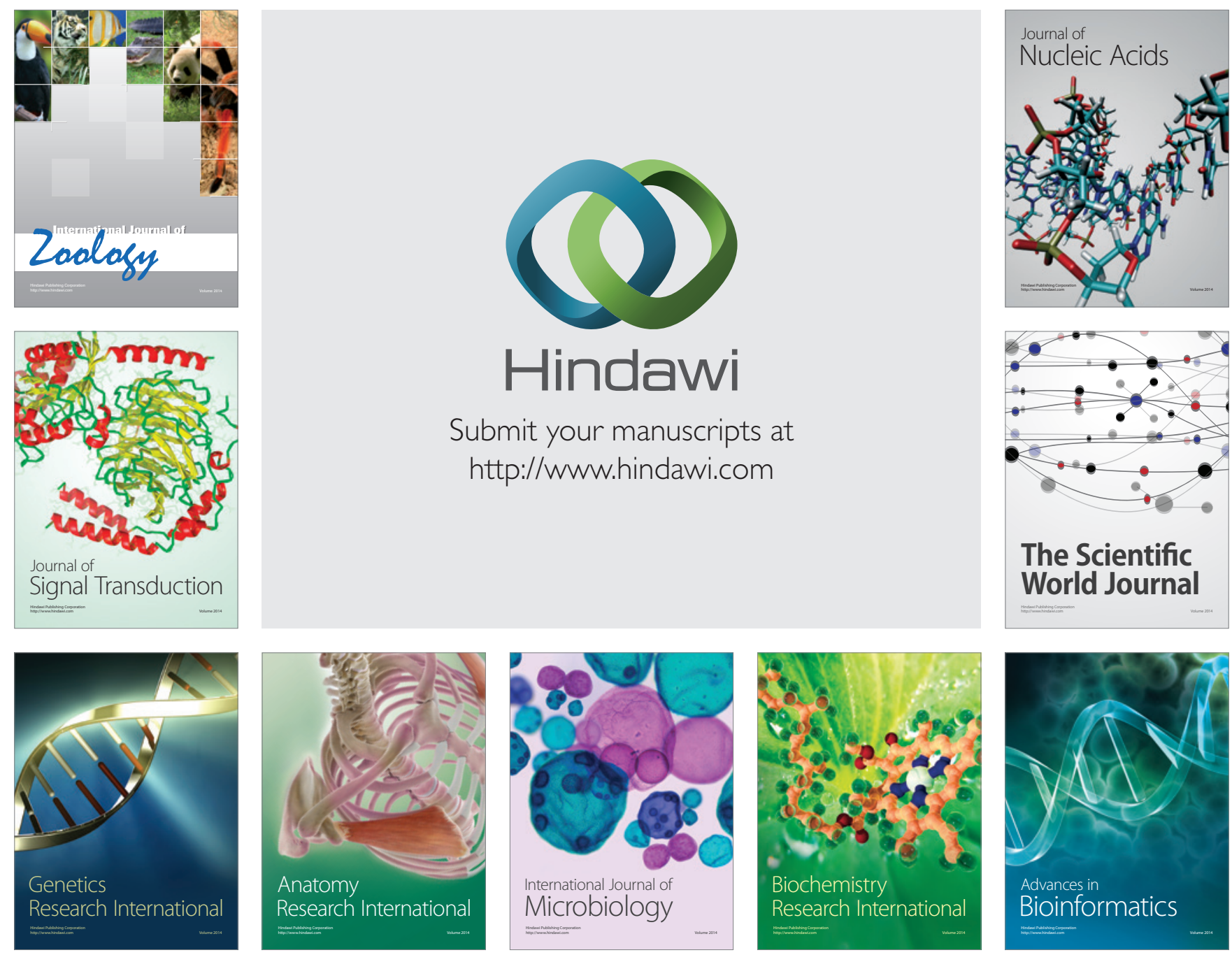

The Scientific World Journal
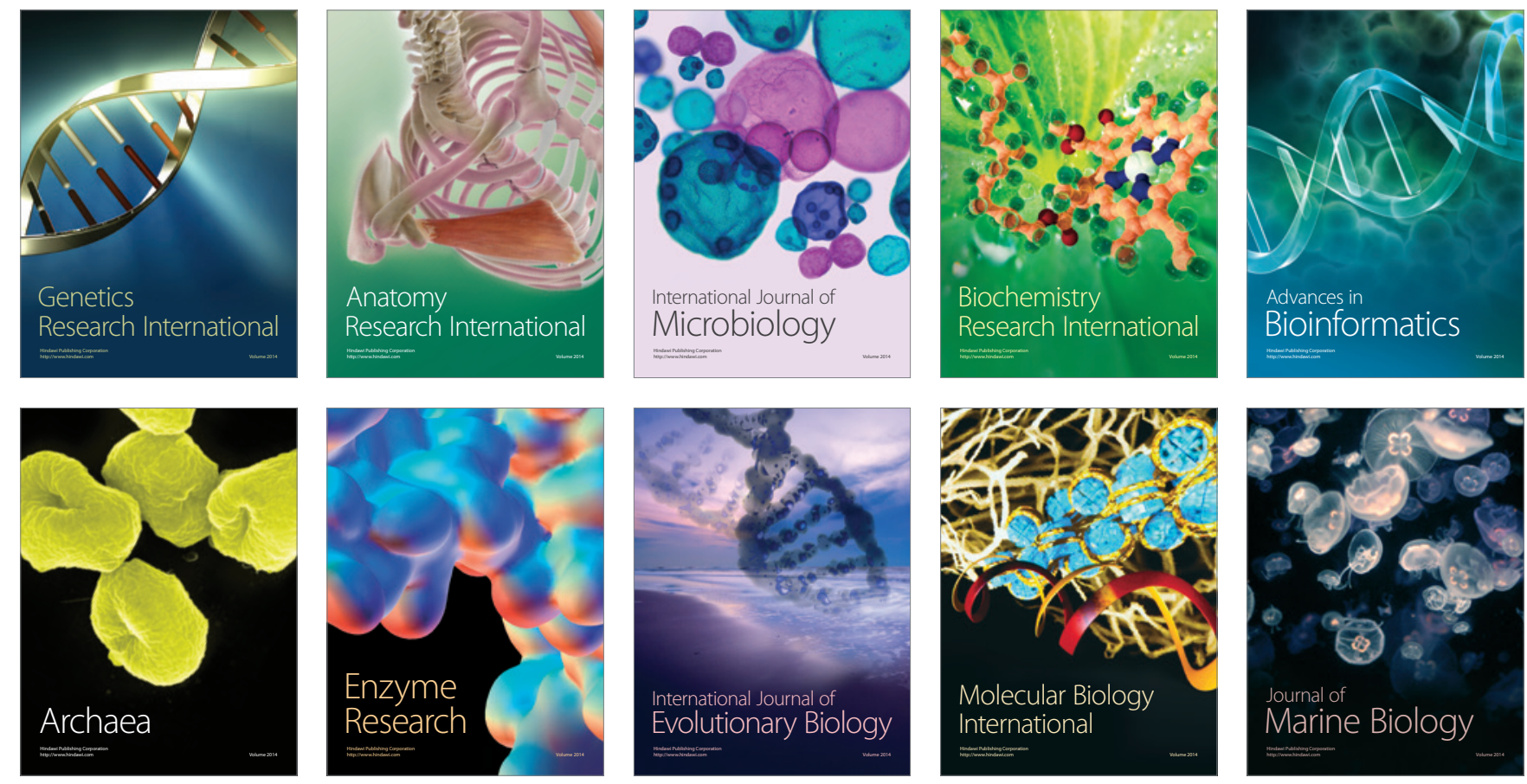